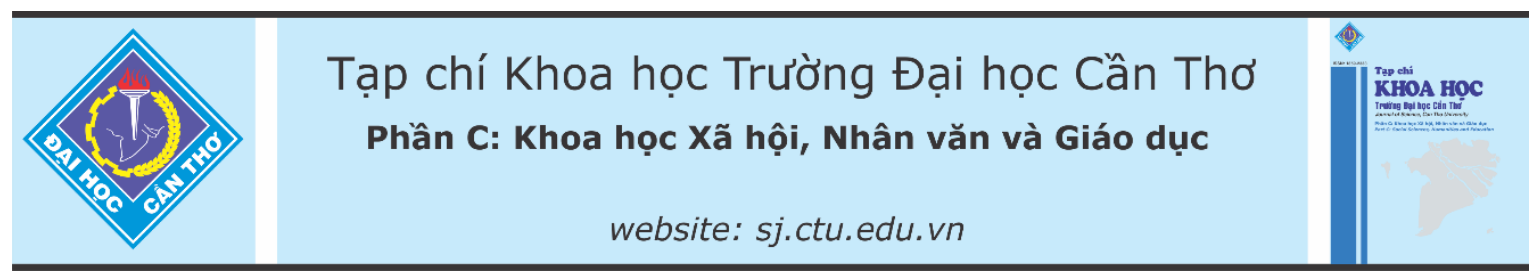

DOI:10.22144/ctu.jvn.2021.161

\title{
CÁC NHÂN TỐ ẢNH HƯởNG ĐẾN SỰ HẤP DÃ̃N CỦA ĐIỀM ĐẾN DU LỊCH PHÚ QUỐC, TỈNH KIÊN GIANG
}

\author{
Trương Trí Thông ${ }^{1 *}$ và Tô Diễm Phụng ${ }^{2}$ \\ ${ }^{1}$ Khoa Du lịch, Truoòng Cao đẳng Kiên Giang \\ ${ }^{2}$ Sinh viên ngành Quản trị Khách sạn, Khoa Du lịch, Truòng Cao đẳng Kiên Giang \\ *Nguò̀i chịu trách nhiệm về bài viết: Trưong Trí Thông (email: ttthong@kgc.edu.vn)
}

\section{Thông tin chung:}

Ngày nhận bài: 02/05/2021

Ngày nhận bài sủa: 22/05/2021

Ngày duyệt đăng: 29/10/2021

Title:

Factors influencing the attractiveness of Phu Quoc tourist destination, in Kien Giang province

\section{Tù khóa:}

Điểm đến du lịch, nhân tố ảnh huởng, sư hấp dẫn, thành phố Phú Quốc, tỉnh Kiên Giang

\section{Keywords:}

Attraction, factors influence, Kien Giang province, Phu Quoc city, tourist destination

\begin{abstract}
Research the factors influencing the attractiveness of destination have the important role of development of the tourist destination. The study is aimed to address the factors impacting the attractiveness of Phu Quoc tourist destination, in Kien Giang Province. The result showed that there are eleven factors that influence the attractiveness of Phu Quoc tourist destination, in Kien Giang Province: (1) Humans resources, (2) Hygiene and no solicit tourists, (3) Price, (4) Material facilities and souvenir, (5) Tourism resources, (6) Safety and security, (7) Infrastructure, (8) Advertisement and promotion policies, (9) Relics and beaches, (10) Events, festivals and ecology, nature, and (11) Night entertainment. Based on the outcome, this study also provides some suggestions were proposed to increase the attractiveness of Phu Quoc tourist destination more in the future.
\end{abstract}

\section{TÓM TẮT}

Nghiên cưu các nhân tố ảnh huởng đến sự hấp dẫn của điểm đến có ý nghĩa quan trọng đối với sụ tồn tại và phát triển của điểm du lịch. Mục tiêu cứa nghiên cứu này tập trung xác định các nhân tố ảnh huơơng đến sự hấp dẫn của điểm đến du lịch Phú Quốc, tỉnh Kiên Giang. Kết quả nghiên cứu cho thấy có 11 nhân tố ảnh hương đến sư hấp dẫn của điểm đến du lịch Phú Quốc, tỉnh Kiên Giang: (1) Nguồn nhân lực, (2) Vệ sinh và không có tình trạng chèo kéo, (3) Giá cả, (4) Co sở vật chất kỹ thuật và quà lưu niệm, (5) Tài nguyên du lịch, (6) An toàn và an ninh, (7) Co sở ha tầng, (8) Quảng bá và xúc tiến, (9) Các di tích và bãi biển, (10) Sụ kiện, lễ hộ và sinh thái, tự nhiên, và (11) Dịch vu giải trí về đêm. Tù đó, một số khuyến nghị được đề xuất nhằm tăng súc hấp dẫn của điểm đến Phú Quốc hơn nũa trong thời gian tới.

\section{1. ĐặT VẤN Đề}

Sự xuất hiện của du lịch là một phương tiện để thúc đẩy nền kinh tế quốc gia hoặc khu vực tăng trưởng, vì nó có thể mang lại đầu tư, tạo việc làm và thúc đẩy các mặt hàng thủ công và mỹ nghệ tại địa phương (Pandey et al., 1995). Chính vì vậy, các thành phố và quốc gia trên thế giới đang chuyển sang đầu tư cho ngành dịch vụ du lịch như một yếu tố quan trọng trong sự phát triển kinh tế và xã hội.

Thành phố Phú Quốc được xác định là một trong 4 vùng du lịch trọng điểm của tỉnh Kiên Giang trong định hướng của Chiến lược phát triển sản phẩm tỉnh 
Kiên Giang đến năm 2020, tầm nhìn đến năm 2030. Phú Quốc là thành phố đảo duy nhất ở nước ta có nhiều tiềm năng phát triển các loại hình du lịch như biển đảo, nghỉ dưỡng, sinh thái, văn hóa và du lịch MICE. Cùng với đó, Phú Quốc còn là nơi diễn ra nhiều sự kiện lớn, nhất là các cuộc thi về sắc đẹp như Hoa hậu Việt Nam năm 2014, Hoa hậu Hòa bình Thế giới năm 2017, Hoa hậu Biển Việt Nam toàn cầu năm 2018. Vì thế, Phú Quốc đang là điểm du lịch hấp dẫn và thu hút nhiều du khách, thể hiện qua số lượng du khách đến Phú Quốc hằng năm đều tăng. Tổng số lượng khách du lịch đến Phú Quốc năm 2017 là 2.963 .395 lượt, tăng $11,8 \%$ so với năm 2016 (Trần Linh, 2018); và đến năm 2019, Phú Quốc đã đón được hơn 5,1 triệu lượt khách du lịch, trong đó có hơn 671.000 lượt khách quốc tế (Thanh Thanh, 2020). Cùng với đó, Quyết định số 147/QĐTTg của Thủ tướng Chính phủ phê duyệt "Chiến lược phát triển du lịch Việt Nam đến năm 2030”, trong đó chú trọng xây dựng đảo Phú Quốc trở thành trung tâm dịch vụ du lịch giao thương quốc tế hiện đại, chất lượng cao trong khu vực; đầu tư phát triển các sản phẩm dịch vụ như mua sắm, vui chơi giải trí, thể dục thể thao... chất lượng cao phục vụ du lịch tại Phú Quốc (Thủ tướng Chính phủ, 2020). Để đưa được sự phát triển ở điểm du lịch nói chung và Phú Quốc nói riêng, theo nhiều nhà nghiên cứu cho rằng một điểm đến du lịch thành công hơn so với những điểm đến khác thì cần xác định sự hấp dẫn của điểm đến đó đối với du khách (Formica, 2000). Bởi vì sức hấp dẫn của điểm đến là một thành phần thiết yếu để phát triển thành công điểm đến du lịch đó $(\mathrm{Hu} \&$ Wall, 2005). Điểm đến du lịch Phú Quốc có gì hấp dẫn du khách cũng như nhân tố nào ảnh hưởng đến sự hấp dẫn ở điểm đến du lịch Phú Quốc, tỉnh Kiên Giang thì chưa được xác định và nghiên cứu kỹ.

Từ thực tế đó, nghiên cứu được thực hiện nhằm mục đích xác định các nhân tố ảnh hưởng đến sự hấp dần của điểm đến du lịch Phú Quốc, tỉnh Kiên Giang, từ đó đề xuất một số giải pháp giúp nâng cao sự hấp dẫn của điểm đến này trong thời gian tới. Kết quả nghiên cứu có ý nghĩa trong việc cung cấp những thông tin và giải pháp thực tiễn góp phần thu hút du khách đến với Phú Quốc hơn cũng như tăng sức cạnh tranh với các điểm đến khác trong vùng.

\section{PHƯƠNG PHÁP NGHIÊN CÚU}

\subsection{Mô hình nghiên cứu}

Những công trình đầu tiên về các điểm tham quan đã khẳng định không có điểm tham quan thì không có khách du lịch (Gunn, 1972, trích bởi Ngwira \& Kankhuni, 2018). Có nhiều cách để kiểm tra các yếu tố tác động đến sự lựa chọn và quyết định của du khách đến điểm đến du lịch, một cách phổ biến là xem xét sự hấp dẫn của các điểm tham quan, bởi vì sự hấp dẫn của các điểm đến, điểm tham quan là lý do để khách du lịch đến du lịch một điểm đến cụ thể (Richards, 2002), sức hấp dẫn càng mạnh thì khả năng thu hút khách du lịch đến điểm đó càng cao (McIntosh et al., 1990; trích bởi Zhou, 2005) và đây là cơ chế để kéo và thúc đẩy du khách đi du lịch (Benur \& Bramwell, 2015). Tính hấp dẫn của điểm đến du lịch khuyến khích khách du lịch tới tham quan và lưu trú tại điểm đến; vì thế, giá trị chủ yếu của tính hấp dẫn điểm đến chính là sức cuốn hút khách du lịch (Nguyễn Anh Tuấn, 2010). Do đó, việc xác định các nhân tố hấp dẫn của điểm đến góp phần tạo nên sự cạnh tranh thành công đối với các điểm đến khác trong thị trường du lịch.

Theo Vengesayi (2003), các tài nguyên của điểm đến và các hoạt động là những nhân tố cơ bản tạo nên sự hấp dẫn của điểm đến như điều kiện tự nhiên, lịch sử, văn hóa, các sự kiện và các hoạt động du lịch, giải trí,... các nhân tố này sẽ cung cấp cho du khách có thêm nhiều lựa chọn và đó chính là nhân tố 'kéo' đối với du khách. Tương tự như thế, Harris and Howard (1996) cho rằng, sự hấp dẫn của một điểm du lịch bao gồm nhân tố tự nhiên và nhân tố văn hóa với khả năng đáp ứng nhu cầu giải trí của khách du lịch bao gồm: khí hậu, bảo tàng hoặc buổi biểu diễn. Ngoài ra, theo các kết quả nghiên cứu những nhân tố hấp dẫn du khách đối với điểm đến bao gồm các điểm tham quan, các hoạt động và trải nghiệm (Lew, 1987), tài nguyên du lịch, khí hậu, văn hóa, ẩm thực, giá trị lịch sử, cơ sở vật chất kỹ thuật, cơ sở hạ tầng, dịch vụ, sự an ninh (Kozak \& Rimmington, 1998), giá cả, dịch vụ và giải trí (Swarbrooke, 1999), sự ổn định về chính trị, sự an toàn và thuận tiện, vệ sinh, nơi mua sắm hợp lý, ẩm thực (Hui \& Wan, 2003), cảnh quan, văn hóa và lịch sử, hoạt động giải trí, dịch vụ, khả năng tiếp cận, thái độ của người dân địa phương, sự an toàn, thư giản, khí hậu, giá cả (Zhou, 2005), vệ sinh và không có tình trạng thách giá, giá cả, vui chơi giải trí, con người, tài nguyên du lịch, cơ sở lưu trú, cơ sở ăn uống và bến tàu du lịch, đường sá và phương tiện vận chuyển, quảng bá và xúc tiến, an toàn và an ninh (Trương Trí Thông, 2019).

Trên cơ sở các nhân tố hấp dẫn ở điểm đến du lịch được đề cập cùng với tình hình thực tế ở địa bàn nghiên cứu, các tiêu chí và biến quan sát được đề xuất trong mô hình nghiên cứu như sau: 


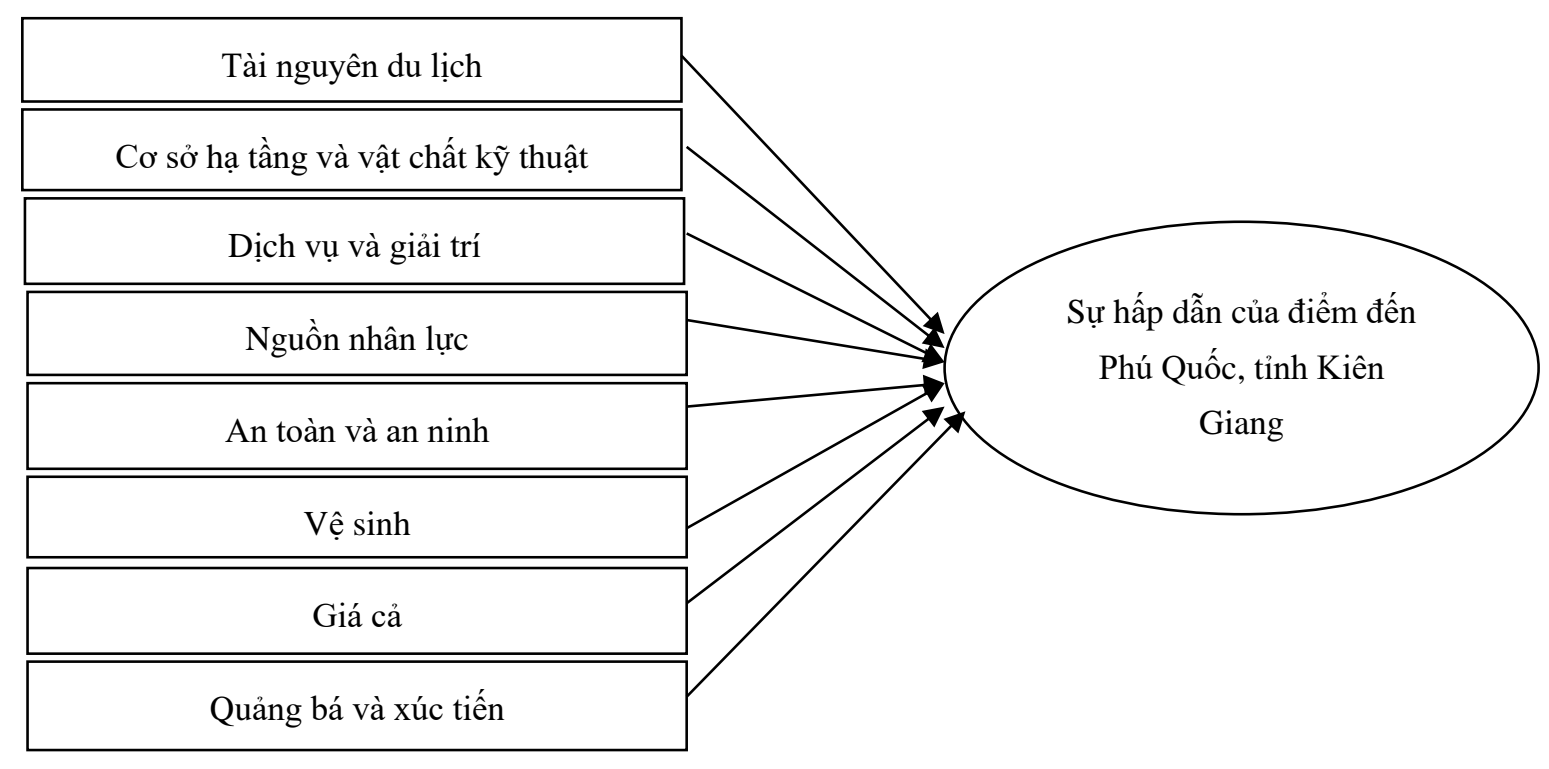

Hình 1. Mô hình nghiên cứu

Nguồn: Nhóm nghiên cứu đề xuất, 2020

\section{Bảng 1. Tổng hợp nguồn tiêu chí của nghiên cứu}

\begin{tabular}{|c|c|c|c|}
\hline TT & Tiêu chí & Ký hiệu tiêu chí & Nguồn \\
\hline 1 & Tài nguyên du lịch & TNDL & $\begin{array}{l}\text { Harris and Howard (1996); Kozak and } \\
\text { Rimmington (1998); Lew (1987); Trương Trí } \\
\text { Thông (2019); Vengesayi (2003); Zhou (2005). }\end{array}$ \\
\hline 2 & $\begin{array}{l}\text { Cơ sở hạ tầng và vật } \\
\text { chât kỹ thuật }\end{array}$ & CSHT & $\begin{array}{l}\text { Hui and Wan (2003); Kozak and Rimmington } \\
\text { (1996); Trương Trí Thông (2019). } \\
\text { Harris and Howard (1996); Kozak and }\end{array}$ \\
\hline 3 & Dịch vụ và giải trí & DVGT & $\begin{array}{l}\text { Rimmington (1998); Lew (1987); Swarbrooke } \\
\text { (1999); Trương Trí Thông (2019); Vengesayi } \\
\text { (2003); Zhou (2005). }\end{array}$ \\
\hline 4 & Nguồn nhân lực & NNL & Trương Trí Thông (2019); Zhou (2005). \\
\hline 5 & An toàn và an ninh & ATAN & $\begin{array}{l}\text { Hui and Wan (2003); Kozak and Rimmington } \\
\text { (1998); Zhou (2005); Trương Trí Thông (2019). }\end{array}$ \\
\hline 6 & Vệ sinh & VS & Hui and Wan (2003); Trương Trí Thông (2019). \\
\hline 7 & Giá cả & GC & $\begin{array}{l}\text { Swarbrooke (1999); Trương Trí Thông (2019); } \\
\text { Zhou (2005). }\end{array}$ \\
\hline 8 & Quảng bá và xúc tiến & QBXT & Trương Trí Thông (2019). \\
\hline
\end{tabular}

Nguồn: Nhóm nghiên cúu tổng hợp, 2020

\subsection{Phương pháp thu thập và xử lý dữ liệu sơ cấp}

Nghiên cứu sử dụng bảng hỏi để thu thập dữ liệu sơ cấp. Do số lượng khách du lịch có sự chênh lệch, không giống nhau giữa các khoảng thời gian trong năm nên phương pháp chọn mẫu thuận tiện được sử dụng trong nghiên cứu này. Mẫu nghiên cứu bao gồm 301 du khách đang du lịch tại Phú Quốc. Theo Hoàng Trọng và Chu Nguyề̃n Mộng Ngọc (2008), cỡ mẫu ít nhất phải bằng 4 hay 5 lần số biến trong phân tích nhân tố, trong nghiên cứu này sử dụng 43 biến quan sát do đó số lượng mẫu 301 là phù hợp $(\mathrm{n}=43 \times 5=215)$. Thời gian thu thập dữ liệu được tiến hành từ tháng 5 năm 2020 đến tháng 1 năm 2021. Dữ liệu sơ cấp sau khi thu thập được sẽ tiến hành phân tích bằng phần mềm SPSS 20.0 với các phương pháp như sau:

(1) Phương pháp thống kê mô tả dưới dạng giá trị trung bình được dùng để đo lường mức độ hấp dần của điểm đến du lịch Phú Quốc thông qua đánh giá của du khách. Giá trị trung bình được đánh giá bằng thang đo Likert 5 mức độ, giá trị trung bình 
từng mức độ sẽ là: mức độ $1(1,00$ - 1,80 = rất không hấp dẫn), mức $2(1,81-2,60=$ không hấp dẫn), mức $3(2,61-3,40=$ không phải hấp dẫn cũng không phải không hấp dẫn), mức $4(3,41-4,20=$ hấp dẫn), mức $5(4,21-5,00=$ rất hấp dẫn).

(2) Phương pháp đánh giá độ tin cậy của thang đo được sử dụng để đánh giá độ tin cậy của các thang đo và biến quan sát trong nghiên cứu có phù hợp hay không trước khi đưa vào phân tích nhân tố khám phá. Để tính Cronbach's Alpha cho một thang đo phải có tối thiếu là ba biến đo lường, hệ số Cronbach's Alpha có giá trị biến thiên trong khoảng $[0,1]$ (Hoàng Trọng \& Chu Nguyễn Mộng Ngọc, 2008). Nhiều nghiên cứu cũng đồng ý rằng khi Cronbach's Alpha từ 0,8 trở lên đến gần 1,0 thì thang đo lường là tốt, từ 0,7 đến gần 0,8 là sử dụng được (Hoàng Trọng \& Chu Nguyễn Mộng Ngọc, 2008). Ngoài ra, đối với biến đo lường đảm bảo độ tin cậy khi có hệ số tương quan biến - tổng $\geq 0,3$ (Nunnally \& Bernstein, 1994, trích bởi Nguyễn Đình Thọ, 2011).

(3) Phương pháp phân tích nhân tố khám phá được sử dụng để xác định những nhân tố ảnh hưởng đến sự hấp dẫn của điểm đến du lịch Phú Quốc, tỉnh Kiên Giang. Để phân tích nhân tố khám phá, trước tiên cần phải đánh giá độ tin cậy của từng thang đo, xem thang đo nào tin cậy và loại những thang đo không tin cậy (hệ số tương quan biến - tổng $\geq 0,3$ ). Dùng kiểm định $\mathrm{KMO}$ và Bartlett (để kiểm định mức độ thích hợp của các biến đã đánh giá độ tin cậy trước khi chính thức tiến hành phân tích nhân tố khám phá. Theo Hoàng Trọng và $\mathrm{Chu}$ Nguyễn Mộng Ngọc (2008), nếu kiểm định Bartlett có giá trị Sig. $>0,05$ (không có ý nghĩa thống kê) và thì không nên áp dụng phân tích nhân tố khám phá. Ngoài ra, theo Kaiser (1974, trích bởi Nguyễn Đình Thọ, 2011) cho rằng $\mathrm{KMO} \geq 0,9$ : Rất tốt, $\mathrm{KMO} \geq 0,8$ : Tốt, $\mathrm{KMO} \geq 0,7$ : Được, $\mathrm{KMO} \geq 0$,6: Tạm được, $\mathrm{KMO} \geq 0,5:$ Xấu, $\mathrm{KMO}<0,5$ : Không thể chấp nhận được. Bên cạnh đó, tổng phương sai giải thích ở bảng Total Variance Explained $>50 \%$ (Lê Văn Huy \& Trương Trần Trâm Anh, 2012). Dựa vào bảng ma trận nhân tố sau khi xoay để xác định số lượng nhân tố. Khi xác định được các nhân tố ảnh hưởng sẽ tiến hành đặt tên cho các nhân tố mới vừa tìm được.

(4) Để xác định sự tương quan giữa sự hấp dẫn với sự hài lòng, dự định quay lại và dự định giới thiệu người thân, bạn bè về điểm đến du lịch Phú Quốc, tỉnh Kiên Giang, nghiên cứu sử dụng phương pháp phân tích tương quan cặp. Theo Field (2009), $|\mathrm{r}|<0,1$ là tương quan rất yếu, $|\mathrm{r}|<0,3$ là tương quan yếu, $|\mathrm{r}|<0,5$ tương quan trung bình và $|\mathrm{r}|>$ 0,5 là tương quan mạnh.

\section{KÊT QUẢ VÀ THẢO LUẬN}

\subsection{Các nhân tố ảnh hưởng đến sự hấp dẫn của điểm đến du lịch Phú Quốc}

Để tiến hành xác định các nhân tố ảnh hưởng đến sự hấp dẫn của điểm đến du lịch Phú Quốc, nghiên cứu thực hiện phương pháp phân tích nhân tố khám phá. Để tiến hành phân tích nhân tố khám phá, các tiêu chí và biến quan sát được đánh giá bằng hệ số Cronbach's Alpha. Sau khi đánh giá 8 tiêu chí với 43 biến quan sát, có 03 biến bị loại do có hệ số tương quan biến-tổng < 0,3 (DVGT3, VS1, VS4). Như vậy, còn lại 40 biến quan sát đảm bảo độ tin cậy và đủ điều kiện để phân tích nhân tố khám phá (Bảng 2).

Bảng 2. Hệ số Cronbach's Alpha của thang đo

\begin{tabular}{lclcc}
\hline Tiêu chí & $\begin{array}{c}\text { Số biến } \\
\text { quan sát }\end{array}$ & Biến bị loại & $\begin{array}{c}\text { Cronbach's } \\
\text { Alpha }\end{array}$ & $\begin{array}{c}\text { Hệ số tương quan } \\
\text { biến-tông }\end{array}$ \\
\hline Tài nguyên du lịch & 8 & & 0,841 & $0,411 \rightarrow 0,697$ \\
Cơ sở hạ tầng & 7 & & 0,796 & $0,445 \rightarrow 0,628$ \\
Dịch vụ giải trí & 4 & DVGT3 & 0,737 & $0,450 \rightarrow 0,635$ \\
Nguồn nhân lực & 5 & & 0,868 & $0,558 \rightarrow 0,784$ \\
An toàn và an ninh & 5 & & 0,717 & $0,368 \rightarrow 0,618$ \\
Vệ sinh & 7 & VS1, VS4 & 0,838 & $0,558 \rightarrow 0,689$ \\
Giá cả & 4 & & 0,863 & $0,582 \rightarrow 0,812$ \\
Quảng bá xúc tiến & 3 & & 0,768 & $0,550 \rightarrow 0,683$ \\
\hline
\end{tabular}

Nguồn: Kết quả khảo sát năm 2021, n=301

Dùng kiểm định $\mathrm{KMO}$ và Bartlett để kiểm định mức độ thích hợp của các biến đã đánh giá độ tin cậy trước khi chính thức tiến hành phân tích nhân tố khám phá. Sau khi kiểm định KMO và Bartlett, chỉ số của dữ liệu nghiên cứu $=0,734$ (chỉ số $\mathrm{KMO}$ sử dụng được) và kiểm định Bartlett có giá trị Sig. = $0,000(<0,05)$ (Bảng 3). Vì vậy, dữ liệu này đủ điều kiện đề phân tích nhân tố khám phá. 


\section{Bảng 3. Kiểm định KMO và Bartlett}

\section{Kiểm đinh KMO và Bartlett's Test}

Kaiser-Meyer-Olkin Measure of Sampling Adequacy.

Bartlett's Test of Approx. Chi-Square $\quad 8981.340$

Sphericity of Approx. Chi-Square
Df
Sig.

741

.000

Nguồn: Kết quả khảo sát năm 2021, n=301

Theo Hair et al. (1998), mẫu nghiên cứu là 301 thì hệ số tải nhân tố phải $\geq 0,35$. Sau khi phân tích, trong 40 biến quan sát thì có 01 biến quan sát bị loại vì hệ số tải nhân tố < 0,35 (TNDL1). Ngoài ra, tổng phương sai giải thích ở bảng Total Variance Explained $=73,820 \%$ (>50\%); dựa vào bảng Total Variance Explained cho biết có 11 nhân tố ảnh hưởng và cột Cumulative $\%$ (\% tích lũy) cho biết có 11 nhân tố giải thích được $73,820 \%$ biến thiên của dữ liệu. Dựa vào bảng ma trận điểm số nhân tố (Bảng 4) ta có thể kết luận, có 11 nhân tố ảnh hưởng đến sự hấp dẫn ở điểm đến du lịch Phú Quốc.

Bảng 4. Ma trận điểm số nhân tố

\begin{tabular}{|c|c|c|c|c|c|c|c|c|c|c|c|}
\hline \multirow{2}{*}{$\begin{array}{l}\text { Biến } \\
\text { Quan sát }\end{array}$} & \multicolumn{11}{|c|}{ Nhân tố } \\
\hline & 1 & 2 & 3 & 4 & 5 & 6 & 7 & 8 & 9 & 10 & 11 \\
\hline NNL4 & 0,823 & & & & & & & & & & \\
\hline NNL5 & 0,816 & & & & & & & & & & \\
\hline NNL2 & 0763 & & & & & & & & & & \\
\hline NNL3 & 0,756 & & & & & & & & & & \\
\hline NNL1 & 0,653 & & & & & & & & & & \\
\hline VS5 & & 0,851 & & & & & & & & & \\
\hline VS2 & & 0,849 & & & & & & & & & \\
\hline VS7 & & 0,736 & & & & & & & & & \\
\hline VS6 & & 0,620 & & & & & & & & & \\
\hline ATAN1 & & 0,527 & & & & & & & & & \\
\hline VS3 & & 0,473 & & & & & & & & & \\
\hline GC3 & & & 0,889 & & & & & & & & \\
\hline $\mathrm{GC} 2$ & & & 0,868 & & & & & & & & \\
\hline GC4 & & & 0,819 & & & & & & & & \\
\hline GC1 & & & 0,683 & & & & & & & & \\
\hline CSHT5 & & & & 0,778 & & & & & & & \\
\hline CSHT7 & & & & 0,757 & & & & & & & \\
\hline CSHT6 & & & & 0,681 & & & & & & & \\
\hline CSHT4 & & & & 0,587 & & & & & & & \\
\hline DVGT2 & & & & 0,538 & & & & & & & \\
\hline DVGT1 & & & & 0,462 & & & & & & & \\
\hline TNDL4 & & & & & 0,902 & & & & & & \\
\hline TNDL7 & & & & & 0,889 & & & & & & \\
\hline TNDL8 & & & & & 0,750 & & & & & & \\
\hline ATAN4 & & & & & & 0,834 & & & & & \\
\hline ATAN2 & & & & & & 0,817 & & & & & \\
\hline ATAN3 & & & & & & 0,803 & & & & & \\
\hline ATAN5 & & & & & & 0,447 & & & & & \\
\hline CSHT2 & & & & & & & 0,879 & & & & \\
\hline CSHT1 & & & & & & & 0,738 & & & & \\
\hline CSHT3 & & & & & & & 0,736 & & & & \\
\hline QBXT2 & & & & & & & & 0,845 & & & \\
\hline QBXT3 & & & & & & & & 0,812 & & & \\
\hline QBXT1 & & & & & & & & 0,690 & & & \\
\hline TNDL5 & & & & & & & & & 0,841 & & \\
\hline TNDL2 & & & & & & & & & 0,829 & & \\
\hline TNDL6 & & & & & & & & & & 0,897 & \\
\hline TNDL3 & & & & & & & & & & 0,889 & \\
\hline DVGT4 & & & & & & & & & & & 0,688 \\
\hline
\end{tabular}

Nguồn: Kết quả khảo sát năm 2021, n=301 
Dựa vào bảng ma trận điểm số nhân tố (Bảng 4), có các phương trình nhân tố như sau:

$\mathrm{F} 1=0,823 \mathrm{NNL} 4+0,816 \mathrm{NNL} 5+0,763 \mathrm{NNL} 2+$ $0,756 \mathrm{NNL} 3+0,653 \mathrm{NNL} 1$

Nhân tố 1 gồm 05 biến: NNL4 (Nhân viên du lịch thân thiện và niềm nở), NNL5 (Nhân viên du lịch có kiến thức và nghiệp vụ tốt), NNL2 (Nhân viên du lịch có phong cách phục vụ chuyên nghiệp), NNL3 (Nhân viên du lịch sẵn sàng giúp đỡ) và NNL1 (Người dân địa phương có tính lịch sự và thân thiện). Nhân tố này được đặt tên là "Nguồn nhân lực".

$\mathrm{F} 2=0,851 \mathrm{VS} 5+0,849 \mathrm{VS} 2+0,736 \mathrm{VS} 7+$ $0,620 \mathrm{VS} 6+0,527$ ATAN $1+0,473 \mathrm{VS} 3$

Nhân tố 2 gồm của 06 biến: VS5 (Mức độ sạch sẽ của bến tàu du lịch), VS2 (Mức độ sạch sẽ của cơ sở lưu trú), VS7 (Các điểm du lịch được bố trí đầy đủ thùng rác), VS6 (Mức độ sạch sẽ của sân bay), ATAN1 (Công tác quản lý tình trạng chèo kéo tốt) và VS3 (Mức độ sạch sẽ của cơ sở ăn uống). Nhân tố này được đặt tên là "Vệ sinh và không có tình trạng chèo kéo".

$\mathrm{F} 3=0,889 \mathrm{GC} 3+0,868 \mathrm{GC} 2+0,819 \mathrm{GC} 4+$ $0,683 \mathrm{GC} 1$

Nhân tố 3 gồm 04 biến: GC3 (Giá cả ăn uống hợp lý), GC2 (Giá cả mua sắm hợp lý), GC4 (Giá cả lưu trú hợp lý) và GC1 (Giá cả tham quan hợp lý). Nhân tố này được đặt tên là "Giá cả".

\section{$\mathrm{F} 4=0,778 \mathrm{CSHT} 5+0,757 \mathrm{CSHT} 7+$ 0,681 CSHT6 + 0,587CSHT4 + 0,538DVGT2 + 0,462DVGT1}

Nhân tố 4 bao gồm 06 biến: CSHT5 (Mức độ đầy đủ của sân bay quốc tế), CSHT7 (Mức độ đầy đủ của nhà vệ sinh công cộng), CSHT6 (Mức độ đầy đủ của bến tàu du lịch), CSHT4 (Mức độ đa dạng của cơ sở lưu trú), DVGT2 (Sự đa dạng và đặc trưng của quà lưu niệm) và DVGT1 (Có nhiều địa điểm mua sắm). Nhân tố này được đặt tên là "Cơ sở vật chất kỹ thuật và quà lưu niệm".

\section{$\mathrm{F} 5=0,902 \mathrm{TNDL} 4+0,889 \mathrm{TNDL} 7+$ 0,750TNDL8}

Nhân tố 5 gồm 03 biến: TNDL4 (Sự đa dạng về hệ sinh thái biển đảo), TNDL7 (Sự hấp dẫn của ẩm thực) và TNDL8 (Sự hấp dẫn của các làng nghề). Nhân tố này được đặt tên là "Tài nguyên du lịch".

$\mathrm{F} 6=$
$0,803 \mathrm{ATAN} 3$
0,034 ATAN4 $4+\underset{\mathrm{ATAN}}{+}$

Nhân tố 6 gồm 04 biến: ATAN4 (Công tác quản lý tình trạng trộm cắp tốt), ATAN2 (Công tác quản lý tình trạng thách giá tốt), ATAN3 (Công tác quản lý tình trạng ăn xin tốt) và ATAN5 (Sự ổn định về tình hình chính trị). Nhân tố này được đặt tên là "An toàn và an ninh".

\section{$\mathrm{F} 7=0,879 \mathrm{CSHT} 2+0,738 \mathrm{CSHT} 1+$ $0,736 \mathrm{CSHT} 3$}

Nhân tố 7 gồm có 03 biến: CSHT2 (Chất lượng mặt đường giao thông tại điểm đến tốt), CSHT1 (Sự rộng rãi của đường giao thông tại điểm đến) và CSHT3 (Mức độ đa dạng của cơ sở ăn uống). Nhân tố này được đặt tên là "Cơ sở hạ tầng".

\section{$\mathrm{F} 8=0,845 \mathrm{QBXT} 2+0,812 \mathrm{QBXT} 3+$ 0,690QBXT1}

Nhân tố 8 gồm có 03 biến: QBXT2 (Sự đầy đủ các chương trình du lịch ở Phú Quốc), QBXT3 (Có nhiều chương trình du lịch khuyến mãi ở Phú Quốc) và QBXT1 (Sự bắt mắt của các mẫu quảng cáo về du lịch ở Phú Quốc). Nhân tố này được đặt tên là "Quảng bá và xúc tiến".

\section{$\mathrm{F} 9=0,841 \mathrm{TNDL} 5+0,829 \mathrm{TNDL} 2$}

Nhân tố 9 gồm có 02 biến: TNDL5 (Sự độc đáo, hấp dẫn của các di tích lịch sử - văn hóa) và TNDL2 (Có nhiều bãi biển, bãi tắm đẹp). Nhân tố này được đặt tên là "Các di tích và bãi biển".

\section{$\mathrm{F} 10=0,897 \mathrm{TNDL} 6+0,889 \mathrm{TNDL} 3$}

Nhân tố 10 gồm có 02 biến: TNDL6 (Sự hấp dẫn của các sự kiện, lễ hội) và TNDL3 (Sự độc đáo, hấp dẫn của các điểm tham quan sinh thái, tự nhiên). Nhân tố này được đặt tên là "Sự kiện, lễ hội và sinh thái, tự nhiên".

\section{$\mathrm{F} 11=0,688 \mathrm{DVGT} 4$}

Nhân tố 11 gồm có 01 biến: DVGT4 (Có nhiều dịch vụ giải trí về đêm). Nhân tố này được đặt tên là "Dịch vụ giải trí về đêm".

\section{2. Đánh giá sự hấp dẫn của điểm đến du lịch Phú Quốc}

Theo cảm nhận của du khách, 11 nhân tố ảnh hưởng đến sự hấp dẫn của điểm đến du lịch Phú Quốc lần lượt là: (1) "Nguồn nhân lực", (2) "Vệ sinh và tình trạng chèo kéo", (3) "Giá cá", (4) "Cơ sở vật chất kỹ thuật và quà lưu niệm", (5) "Tài nguyên du lịch", (6) "An toàn và an ninh", (7) "Cơ sở hạ tầng", (8) "Quảng bá và xúc tiến", (9) "Các di tích và bãi biển", (10) "Sự kiện, lễ hội và sinh thái, tự nhiên" và (11) "Dịch vụ giải trí về đêm". Sau đây là đánh giá cụ thể của du khách đối với từng nhân tố: 
Nguồn nhân lực là yếu tố không thể thiếu trong sự phát triển của du lịch nói chung và điểm đến nói riêng. Nguồn nhân lực thể hiện qua nhân viên du lịch và người dân địa phương; trong đó, nhân viên du lịch rất quan trọng bởi vì đây là người trực tiếp phục vụ du khách khi đi du lịch như nhân viên nhà hàng, nhân viên khách sạn, nhân viên khu vui chơi, hướng dẫn viên du lịch,... Chính vì vậy, phong cách phục vụ chuyên nghiệp, thái độ phục vụ tốt rất thu hút du khách. Theo đánh giá của du khách, nguồn nhân lực tại điểm đến Phú Quốc là một nhân tố hấp dẫn đối với du khách $(\mathrm{M}=3,70)$, cụ thể: Nhân viên du lịch có phong cách phục vụ chuyên nghiệp $(\mathrm{M}=3,76)$, nhân viên có kiến thức và nghiệp vụ tốt $(\mathrm{M}=3,72)$, nhân viên thân thiện và niềm nở $(\mathrm{M}=3,71)$, người dân địa phương lịch sự và thân thiện $(\mathrm{M}=3,71)$ và nhân viên du lịch sằn sàng giúp đỡ khách $(\mathrm{M}=3,61)$. Kết quả này giống với kết quả nghiên cứu của Zhou (2005) và Trương Trí Thông (2019).

Vệ sinh và không có tình trạng chèo kéo khách là thực trạng ảnh hưởng đến ngành du lịch của nước ta trong thời gian qua, nó ảnh hưởng rất lớn đến sự thu hút và hấp dẫn của điểm đến, sự hài lòng và lòng trung thành của du khách. Đối với điểm đến Phú Quốc, nhân tố vệ sinh và không có tình trạng chèo kéo được du khách đánh giá là hấp dẫn $(\mathrm{M}=3,47)$, tức là ở Phú Quốc tình trạng vệ sinh, tình trạng chèo kéo vẫn được đảm bảo. Điều này được thể hiện bởi mức độ sạch sẽ của sân bay $(\mathrm{M}=3,63)$, cơ sở ăn uống $(\mathrm{M}=3,58)$, bến tàu du lịch $(\mathrm{M}=3,45)$, cơ sở lưu trú $(\mathrm{M}=3,41)$, việc bố trí đầy đủ thùng rác $(\mathrm{M}=3,41)$. Tuy nhiên, riêng vấn đề công tác quản lý tình trạng chèo kéo thì vẫn còn ở mức bình thường (không phải hấp dẫn cũng không phải không hấp dẫn) với giá trị trung bình là 3,34 .

Giá cả là yếu tố ảnh hưởng đến khả năng chi trả trong chuyến đi của du khách. Một điểm đến với giá cả hợp lý và tương xứng với chất lượng dịch vụ của chuyến đi là điều du khách rất quan tâm hiện nay. Nghiên cứu của Swarbrooke (1999), Trương Trí Thông (2019) và Zhou (2005) cũng cho ra kết quả tương tự. Giá cả của điểm đến Phú Quốc được du khách đánh giá là nhân tố hấp dẫn khi lựa chọn địa điểm du lịch $(\mathrm{M}=3,51)$. Du khách bị hấp dẫn bởi giá cả về tham quan, ăn uống và mua sắm tại Phú Quốc (lần lượt là $\mathrm{M}=3,71, \mathrm{M}=3,51, \mathrm{M}=3,41$ ), còn giá cả lưu trú chưa hấp dẫn du khách $(\mathrm{M}=3,38)$.

Ở các kết quả nghiên cứu trước, "Cơ sở vật chất kỹ thuật" là một nhân tố riêng biệt và "Quà lưu niệm" là một biến phụ thuộc của nhân tố "Dịch vụ giải trí", nhưng ở kết quả của nghiên cứu này thì hai nhân tố đã gom lại thành một nhân tố mới; đây là kết quả nghiên cứu khác so với các kết quả nghiên cứu trước đó. Cơ sở vật chất kỹ thuật và quà lưu niệm được du khách đánh giá là hấp dẫn $(\mathrm{M}=3,39)$, trong đó du khách hấp dẫn bởi sự đầy đủ của bến tàu du lịch $(M=3,65)$, sân bay $(M=3,57)$, nhà vệ sinh công cộng $(\mathrm{M}=3,53)$. Tuy nhiên, cơ sở lưu trú, quà lưu niệm, địa điểm mua sắm chưa được du khách đánh giá cao, còn ở mức độ bình thường (không phải hấp dẫn cũng không phải không hấp dẫn) với giá trị trung bình lần lượt là 3,$36 ; 3,13$ và 3,07 .

Tài nguyên du lịch là một trong những điều kiện riêng để hình thành và phát triển điểm đến. Tài nguyên du lịch còn là đối tượng tạo nên sức hấp dẫn cho du khách, là nguồn lực quan trọng nhất, mang tính quyết định sự phát triển của ngành du lịch (Hoàng Thị Kiều Oanh, 2019). Đồng thời, tài nguyên du lịch còn giúp nảy sinh, đáp ứng nhu cầu nghỉ ngơi và đi du lịch của du khách. Tài nguyên du lịch ở Phú Quốc hấp dẫn du khách $(\mathrm{M}=3,83)$ bởi sự đa dạng về hệ sinh thái biển đảo nơi đây $(\mathrm{M}=3,87)$, có ẩm thực hấp dẫn $(\mathrm{M}=3,87)$ và các làng nghề truyền thống $(\mathrm{M}=3,74)$. Kết quả nghiên cứu này tương tự với kết quả của các tác giả Harris and Howard (1996), Kozak and Rimmington (1998), Lew (1987), Vengesayi (2003), Trương Trí Thông (2019) và Zhou (2005).

An toàn và an ninh ảnh hưởng rất lớn đến quyết định đi du lịch của du khách tại một điểm đến nào đó. Một điểm đến an toàn, tình hình chính trị ổn định, an ninh trật tự được đảm bảo thì sẽ gây ấn tượng tốt và hấp dẫn du khách hơn. Kết quả này tương tự với kết quả nghiên cứu của Hui and Wan (2003), Kozak and Rimmington (1998), Trương Trí Thông (2019) và Zhou (2005). An toàn và an ninh ở điểm đến du lịch Phú Quốc hấp dẫn khách du lịch $(\mathrm{M}=3,69)$ thông qua tình hình chính trị tốt $(\mathrm{M}=3,87)$, công tác quản lý tốt các vấn đề về trật tự an ninh, an toàn xã hội như tình trạng trộm cắp $(\mathrm{M}=3,82)$, thách giá $(\mathrm{M}=3,59)$ và ăn xin $(\mathrm{M}=3,47)$.

Ngoài cơ sở vật chất kỹ thuật thì cơ sở hạ tầng giúp điểm đến đầy đủ tiện nghi và sẵn sàng phục vụ, tiếp đón du khách được chu đáo hơn. Kết quả này giống với kết quả nghiên cứu của Kozak and Rimmington (1998). Cơ sở hạ tầng của Phú Quốc được du khách đánh giá là hấp dẫn $(\mathrm{M}=3,40)$ bởi mức độ đa dạng của cơ sở ăn uống $(\mathrm{M}=3,50)$ và sự rộng rãi của đường giao thông tại điểm đến $(\mathrm{M}=3,42)$. Tuy nhiên, chất lượng mặt đường giao thông tại điểm đến còn chưa mang đến sự hấp dẫn cho du khách $(\mathrm{M}=3,27)$, do đó cần chú trọng đến vấn đề này hơn trong phát triển du lịch Phú Quốc thời gian tới. 
Một trong những nhân tố quan trọng để tạo nên sự hấp dẫn và thu hút du khách đi du lịch tại một điểm đến đó là sức hút của quảng bá và xúc tiến. Bởi vì khi đi du lịch, du khách thường có thói quen tra cứu thông tin trên Internet để xem các thông tin và hình ảnh giới thiệu về điểm đến, xem các chương trình khuyến mãi để so sánh và lựa chọn một nơi mà họ có dự định đi du lịch. Quảng bá và xúc tiến ở Phú Quốc được du khách đánh giá là hấp dẫn $(\mathrm{M}=3,53)$ qua sự bắt mắt của các mẫu quảng cáo về du lịch $(\mathrm{M}=3,54)$, có nhiều chương trình du lịch khuyến mãi $(\mathrm{M}=3,53)$ và có đầy đủ các chương trình du lịch ở Phú Quốc $(\mathrm{M}=3,49)$. Kết quả này tương tự với kết quả của Trương Trí Thông (2019).

Ở các nghiên cứu trước, các di tích và bãi biển là biến phụ thuộc của nhân tố tài nguyên du lịch, nhưng đối với kết quả nghiên cứu này thì "di tích và bãi biển" là một nhân tố mới riêng biệt. Điều này là do Phú Quốc là một trong những điểm du lịch biển đảo nổi tiếng ở đồng bằng sông Cửu Long và được mệnh danh là "Hòn Đảo Ngọc", tại nơi đây có rất nhiều bãi tắm và bãi biển đẹp, nước trong xanh như bãi Sao, bãi Dài, bãi Khem,... Vì vậy, đây là một trong những điều thu hút khách du lịch đến đây. Đặc biệt, Phú Quốc còn có rất nhiều công trình di tích lịch sử - văn hóa hấp dẫn, trong đó nổi tiếng nhất là Nhà tù Phú Quốc (di tích cấp Quốc gia đặc biệt). Di tích và bãi biển ở Phú Quốc được du khách đánh giá là hấp dẫn $(\mathrm{M}=4,03)$ vì có nhiều bãi biển, bãi tắm đẹp $(\mathrm{M}=4,06)$ và có các di tích lịch sử - văn hóa độc đáo, hấp dẫn $(\mathrm{M}=3,99)$. Chính vì vậy, để tiếp tục duy trì và phát huy điểm nổi bật này nhằm thu hút khách $\mathrm{du}$ lịch hơn trong tương lai cần chú ý đến nhân tố "Các di tích và bãi biển" hơn nữa.

Sự kiện, lễ hội và sinh thái, tự nhiên là một nhân tố mới và khác so với các kết quả nghiên cứu trước về sức hấp dẫn của điểm đến du lịch. Ở Phú Quốc du khách đánh giá nhân tố "sự kiện, lễ hội và sinh thái, tự nhiên" là hấp dẫn $(\mathrm{M}=4,03)$ bởi sự độc đáo, hấp dẫn của các điểm tham quan sinh thái, tự nhiên
$(\mathrm{M}=4,03)$, có nhiều sự kiện và lễ hội hấp dẫn $(\mathrm{M}=4,02)$.

Dịch vụ giải trí về đêm là một nhân tố mới được tách ra từ nhân tố dịch vụ giải trí, đây cũng là nhân tố khác so với các nghiên cứu trước đó. Dịch vụ giải trí về đêm ở Phú Quốc được du khách đánh giá là bình thường $(\mathrm{M}=2,97)$ bởi vì chưa có đa dạng dịch vụ giải trí về đêm ở nơi đây. Đây cũng là điều cần phải cải thiện khi phát triển du lịch cũng như muốn nâng cao sự hài lòng và tăng sức hấp dẫn của Phú Quốc đối với du khách.

\subsection{Tương quan giữa sự hấp dẫn với sự hài lòng, dự định quay lại và dự định giới thiệu của du khách về điểm đến du lịch Phú Quốc}

Theo kết quả phân tích, ở mức ý nghĩa $\alpha=0,01$, độ tin cậy 99\% (two tailed Pearson's test), sự hấp dẫn tương quan thuận với sự hài lòng về điểm đến du lịch. Kêt quả kiểm định mối quan hệ giữa hai biến, $\mathrm{r}=0,658$ (điều này có nghĩa là tương quan mạnh) (Bảng 6).

Ngoài ra, ở mức ý nghĩa $\alpha=0,01$, độ tin cậy $99 \%$ (two tailed Pearson's test), sự hấp dẫn tương quan thuận với dự định quay lại ở những lần tiếp theo của du khách đối với điểm đến Phú Quốc. Kết quả kiểm định mối quan hệ giữa hai biến, $\mathrm{r}=0,658$ (điều này có nghĩa là tương quan mạnh) (Bảng 6).

Bên cạnh đó, ở mức ý nghĩa $\alpha=0,01$, độ tin cậy 99\% (two tailed Pearson's test), sự hấp dần tương quan thuận với dự định giới thiệu điểm đến du lịch Phú Quốc ở Kiên Giang cho người thân, bạn bè của du khách. Kết quả kiểm định mối quan hệ giữa hai biến, $\mathrm{r}=0,623$ (tương quan mạnh) (Bảng 6). Điều này có nghĩa, sự hấp dẫn của điểm đến du lịch Phú Quốc có ảnh hưởng đến sự hài lòng và lòng trung thành của du khách, cụ thể là dự định quay lại và giới thiệu cho người thân, bạn bè của họ.

Bảng 6. Tương quan giữa sự hấp dẫn với sự hài lòng, dự định quay lại và dự định giới thiệu du lịch của du khách

\begin{tabular}{|c|c|c|c|c|c|}
\hline & & $\begin{array}{r}\text { Sự } \\
\text { hấp dẫn }\end{array}$ & $\begin{array}{r}\text { Sự } \\
\text { hài lòng }\end{array}$ & $\begin{array}{l}\text { Dự định } \\
\text { quay lại }\end{array}$ & $\begin{array}{r}\begin{array}{r}\text { Dụ̣ định giới } \\
\text { thiệu }\end{array} \\
\end{array}$ \\
\hline Sự hấp dẫn & $\begin{array}{l}\text { Tương quan Person } \\
\text { Sig. (2-phía) }\end{array}$ & 1 & & & \\
\hline Sự hài lòng & $\begin{array}{l}\text { Tương quan Person } \\
\text { Sig. (2-phía) }\end{array}$ & $\begin{array}{r}.658 * * \\
.000 \\
\end{array}$ & 1 & & \\
\hline $\begin{array}{l}\text { Dự định quay } \\
\text { lại }\end{array}$ & $\begin{array}{l}\text { Tương quan Person } \\
\text { Sig. (2-phía) }\end{array}$ & $\begin{array}{r}.658 * * \\
.000 \\
\end{array}$ & & 1 & \\
\hline $\begin{array}{l}\text { Dự định giới } \\
\text { thiệu }\end{array}$ & $\begin{array}{l}\text { Tương quan Person } \\
\text { Sig. (2-phía) }\end{array}$ & $\begin{array}{r}.623 * * \\
.000\end{array}$ & & & 1 \\
\hline
\end{tabular}

Nguồn: Kết quả khảo sát năm 2021, n=301 


\subsection{Một số giải pháp nâng cao sức hấp dẫn của điểm đến Phú Quốc}

Qua kết quả nghiên cứu trên, một số khuyến nghị được đề xuất nhằm tăng sức hấp dẫn của điểm đến Phú Quốc và thu hút du khách hơn trong thời gian tới như sau:

(1) Phát triển nguồn nhân lự: Nhân viên du lịch bao gồm các lĩnh vực nhà hàng, khách sạn, hướng dẫn viên, lữ hành,... của các công ty và doanh nghiệp cần tiếp tục duy trì sự thân thiện, niềm nở của mình trong việc chào đón, phục vụ khách khi đến Phú Quốc, đặc biệt là trong phần chào đón khách tại bến tàu, sân bay khi khách vừa đặt chân đến Phú Quốc (Welcome guest) để tạo được những ấn tượng tốt đẹp đầu tiên đối với khách. Ngoài ra, chất lượng phục vụ của nhân viên du lịch cũng cần tích cực rèn luyện để nâng cao trình độ, tay nghề của mình để có thể phục vụ khách một cách tốt nhất, nhất là trong mùa cao điểm. Đồng thời, các doanh nghiệp cần tạo điều kiện, chủ động liên kết với các cơ sở giáo dục trong địa phương để mở các lớp đào tạo ngắn hạn, lớp tập huấn về du lịch định kỳ để nhân viên của mình có thể nâng cao tay nghề hơn nữa. Bên cạnh đó, nhân viên du lịch cần trau dồi, nâng cao khả năng ngoại ngữ để có thể giao tiếp với khách một cách tốt nhất từ đó nâng cao sự hài lòng của khách đối với điểm đến Phú Quốc. Chính quyền địa phương và cơ quan ngành du lịch cần mở các lớp bồi dưỡng, tập huấn cho người dân có làm du lịch về lợi ích của du lịch, cách ứng xử và giao tiếp với du khách,...; bên cạnh đó, tuyên truyền và khuyến khích duy trì tính hiếu khách và sự thân thiện của người dân địa phương đối với khách phương xa.

(2) Đảm bảo vệ sinh và tình trạng chèo kéo: Tiếp tục duy trì mức độ sạch sẽ của sân bay, bến tàu du lịch, của các cơ sở ăn uống và cơ sở lưu trú. Sân bay và bến tàu cần có đội ngũ nhân viên dọn vệ sinh thường xuyên, có các biển báo cấm vứt rác tại bến tàu. Cần bố trí đầy đủ thùng rác tại các điểm tham quan như ở Suối Tranh, suối Đá Bàn, Rạch Vẹm,... Đặc biệt, cần ra quy định xử phạt đối với các trường hợp du khách và người dân địa phương xả rác bừa bãi, vứt rác xuống biển, nguồn suối,... gây mất vệ sinh, ô nhiễm nguồn nước, nhất là việc du khách cắm trại (picnic) ở Suối Tranh và suối Đá Bàn. Bên cạnh đó, công tác quản lý tình trạng chèo kéo du khách cần được các cơ quan địa phương thắt chặt hơn nữa, nhất là đối với việc bán hàng rong tại các điểm tham quan, tại chợ đêm.

(3) Đảm bảo vấn đề giá cả: Vấn đề giá cả của các dịch vụ lưu trú, ăn uống, tham quan và mua sắm tại Phú Quốc cần được duy trì mức giá ổn định, có niêm yết giá cụ thể; không nên tăng giá vào mùa cao điểm để thu thêm lợi nhuận. Đặc biệt, là giá cả mua sắm tại các cửa hàng cũng như tại các chợ, nhất là chợ đêm cần có bảng giá cụ thể, không được tự ý tăng giá khi gặp khách du lịch.

(4) Hoàn thiện co sở vật chất kỹ thuật và quà luu niệm: Hiện tại, Phú Quốc đã cung cấp đầy đủ các cơ sở vật chất kỹ thuật cơ bản để phục vụ cho du lịch như bến tàu, sân bay, nhà vệ sinh công cộng, đa dạng cơ sở lưu trú từ khách sạn bình dân đến các khu nghỉ dưỡng cao cấp. Tuy nhiên, bến tàu du lịch ở Bãi Vòng cần nâng cấp hơn nữa về việc mở rộng bến tàu để giải quyết trường hợp ùn tắc khi tàu cập bến các xe lớn vào rước khách; bến tàu cần có mái che cho đoạn đường từ nhà chờ ra tàu vì rất nắng, điều này làm ảnh hưởng đến tâm lý và sự hài lòng của du khách; cần xem xét nâng cấp chất lượng mặt đường ở bến tàu ở Bãi Vòng. Các nhà vệ sinh công cộng cần được xây dựng thêm ở các khu vực công cộng như chợ, bến tàu, điểm tham quan,... Các cơ sở bán hàng lưu niệm, các điểm mua sắm ở Phú Quốc cũng đã mở ra rất nhiều nhưng mặt hàng quà lưu niệm chưa thật sự đặc trưng ngoại trừ sản phẩm ngọc trai nhưng giá khá cao, chỉ đáp ứng được một số đối tượng khách; do đó, cần có những sản phẩm lưu niệm nhỏ với các mức giá vừa phải mang đặc trưng hình ảnh của Phú Quốc, để làm được điều này các cơ quan ngành du lịch địa phương cần nghiên cứu thị trường, cần có những cuộc thi thiết kế sản phẩm lưu niệm Phú Quốc, từ đó có thể chọn ra được sản phẩm tiêu biểu cho điểm đến du lịch Phú Quốc cũng như mỗi địa điểm du lịch cũng cần có sản phẩm quà lưu niệm riêng biệt.

(5) Phát triển nguồn tài nguyên du lịch: Hệ sinh thái và môi trường tự nhiên tại Phú Quốc rất đa dạng, có rừng, biển, suối, núi, các hòn đảo nhỏ xung quanh, ... thu hút nhiều du khách. Chính vì vậy, cần khai thác và phát triển nhiều loại hình du lịch, sản phẩm du lịch gắn kết với các tài nguyên du lịch này để phù hợp với nhu cầu của nhiều đối tượng khách khác nhau. Giá trị của nền ẩm thực Phú Quốc cần được phát huy, đặc biệt là nền ẩm thực biển với các loại đặc sản như gỏi cá trích, tiết canh tôm hùm, chả cua,... Đồng thời, những chính sách thu hút người dân làm du lịch bằng làng nghề của họ là cần thiết, góp phần tối ưu hóa việc khai thác và sử dụng hợp lý tài nguyên du lịch, bảo tồn làng nghề truyền thống, đa dạng hóa sản phẩm du lịch.

(6) Đảm bảo an toàn và an ninh: Tình hình chính trị tại Phú Quốc hiện nay vẫn được đảm bảo và ổn định, ngoài ra, các vấn đề về trộm cắp, thách giá và ăn xin vẫn được đảm bảo và quản lý tốt; do đó đây là một trong những điều thu hút và hấp dẫn du khách 
đến du lịch nơi đây. Tuy nhiên, việc tiếp tục duy trì và có chính sách phù hợp để giải quyết và khắc phục những tình trạng này trong tương lai là cần thiết như có các quy định xử phạt chế tài đối với việc thách giá, cần có chính sách đào tạo nghề, tạo công ăn việc làm cho những người ăn xin, có lực lượng cảnh sát du lịch tại điểm đến Phú Quốc để xử lý các trường hợp về trật tự an toàn xã hội cũng như các vấn đề phát sinh liên quan đến hòa bình chính trị.

(7) Hoàn thiện co sở hạ tầng: Một số tuyến đường đến các điểm tham quan còn nhỏ và gồ ghề như tuyến đường đến làng chài Hàm Ninh, Rạch Vẹm, suối Đá Bàn,... Do đó, các cơ quan chức năng địa phương cần nhanh chóng mở rộng các tuyến đường dẫn đến các điểm tham quan cũng như chú trọng đến chất lượng mặt đường của nó để tạo sự thoải mái cho du khách khi đi du lịch.

(8) Tăng cuờng quảng bá và xúc tiến: Cần có thêm nhiều chương trình du lịch đặc sắc riêng về Phú Quốc như du lịch biển đảo, du lịch lặn ngắm san hô, du lịch khám phá, du lịch MICE,... Các chương trình phải cân nhắc đến giá cả, cần phân chia theo khả năng chi trả của từng đối tượng khách như học sinh, sinh viên, thanh - thiếu niên, đối tượng có thu nhập cao, thu nhập khá, trung bình,... Việc quảng bá về điểm đến du lịch Phú Quốc ngoài việc thiết kế các băng rôn, các mẫu quảng cáo trên giấy, brochure,... đa dạng màu sắc, hình ảnh bắt mắt để hấp dẫn, lôi cuốn du khách, thì cần quảng bá bằng các video, các clip giới thiệu về các điềm tham quan, điểm du lịch, vui chơi giải trí, văn hóa ẩm thực, làng nghề, sản phẩm du lịch đặc trưng, $\ldots$ của điểm đến Phú Quốc và phải quảng bá rộng rãi trên ti vi, các trang mạng xã hội được nhiều người sử dụng ngày nay như Facebook, Zalo, Instagram, Tiktok, Youtube, ,... Đồng thời, cơ quan chức năng ngành du lịch và địa phương cần có những cuộc thi ảnh hoặc clip giới thiệu về điểm đến Phú Quốc hoặc các điểm tham quan ở Phú Quốc, qua cuộc thi này cũng góp phần quảng bá hình ảnh điểm đển du lịch Phú Quốc hơn. Bên cạnh đó, có thể mời các Youtuber nổi tiếng để quay các video, clip quảng bá về điểm đến du lịch Phú Quốc.

(9) Bảo tồn các di tích và vệ sinh bãi biển: Phú Quốc có rất nhiều bãi biển và bãi tắm đẹp, nước trong xanh như bãi Sao, bãi Dài, bãi Khem, bãi Thơm, bãi Ông Lang,... đang thu hút rất nhiều du khách, tuy nhiên để đảm bảo sức hấp dẫn của các bãi biển này trong tương lai cần thường xuyên dọn sạch rác thải du lịch ở các bãi tắm, đồng thời cần thiết lập các thùng đựng rác tại các bờ biển và bãi tắm, cần nghiêm cấm cắm trại và ăn uống trên bãi biển vì đây là một trong những nguyên nhân gây ra rác thải nhiều nhất. Đồng thời, các công trình di tích văn hóa - lịch sử ở Phú Quốc cần trùng tu, tôn tạo để tránh tình trạng xuống cấp, có thể duy trì cho du khách đến tham quan thường xuyên; các công trình có thể trùng tu, tôn tạo vào thời gian mùa du lịch thấp điểm; tuy nhiên, trùng tu và tôn tạo không được mất đi nét kiến trúc ban đầu của nó. Đặc biệt, chú trọng vào di tích cấp Quốc gia đặc biệt - Nhà tù Phú Quốc hơn trong việc khai thác du lịch.

(10) Tăng cuờng tổ chức các sự kiện, lễ hội: Phú Quốc được biết đến với nhiều sự kiện và lễ hội lớn cả truyền thống và hiện đại. Các sự kiện và lễ hội góp phần thu hút du khách đến để trải nghiệm và đi du lịch, đồng thời cũng góp phần quảng bá hình ảnh điểm đến của Phú Quốc. Chính vì vậy, chính quyền và cơ quan ngành du lịch địa phương cần tận dụng lợi thế này để phát triển du lịch Phú Quốc hơn nữa thông qua việc khuyến khích các doanh nghiệp tổ chức các sự kiện và lễ hội hiện đại tại các khu vui chơi giải trí, tại khách sạn hoặc resort; tổ chức các cuộc thi sắc đẹp, cuộc thi thời trang mang tầm Quốc gia và Quốc tế tại Phú Quốc; khôi phục và tổ chức lại các lễ hội mang tính truyền thống của người dân xứ biển và của địa phương.

(11) Tăng cuờng hoạt động dịch vu giải trí về đêm: Nhằm nâng cao khả năng chi trả và đáp ứng nhu cầu du lịch của du khách, ngoài việc phát triển các địa điểm và sản phẩm du lịch tham quan ban ngày thì cần chú trọng đến các sản phẩm dịch vụ du lịch về đêm như mở các khu vui chơi giải trí về đêm, các khu chợ đêm ăn uống, các quán bar, vũ trường, các hoạt động văn nghệ đường phố, hoạt động câu mực, ... để tăng sức hấp dẫn và thu hút du khách đến với Phú Quốc hơn nữa.

\section{KẾT LUẬN}

Xác định các nhân tố ảnh hưởng đến sự hấp dẫn của điểm du lịch rất quan trọng đối với sự phát triển du lịch tại điểm đến nói riêng và địa phương nói chung, một mặt giúp đưa ra các giải pháp hiệu quả nhằm nâng cao sức thu hút và hấp dẫn của điểm $\mathrm{du}$ lịch; một mặt tăng sức cạnh tranh với các điểm du lịch khác tại địa phương và khu vực. Do đó, nghiên cứu này được thực hiện đối với điểm đến Phú Quốc, một trong những điểm đến nổi tiếng tại Đồng bằng sông Cửu Long đối với du khách cả trong và ngoài nước.

Kết quả nghiên cứu cho thấy có 11 nhân tố ảnh hưởng đến sự hấp dẫn của điểm đến du lịch Phú Quốc, tỉnh Kiên Giang: (1) Nguồn nhân lực, (2) Vệ sinh và tình trạng chèo kéo, (3) Giá cả, (4) Cơ sở vật chất kỹ thuật và quà lưu niệm, (5) Tài nguyên du lịch, (6) An toàn và an ninh, (7) Cơ sở hạ tầng, (8) 
Quảng bá và xúc tiến, (9) Các di tích và bãi biển, (10) Sự kiện, lễ hội và sinh thái, tự nhiên và (11) Dịch vụ giải trí về đêm. Bên cạnh đó, thông qua kiểm định tương quan biến cho thấy, sự hấp dẫn tương quan thuận với sự hài lòng, dự định quay lại và dự định giới thiệu của du khách đối với điểm đến Phú Quốc. Chính vì vậy, để điểm đến Phú Quốc hấp dẫn hơn đối với du khách thì cơ quan chức năng và chính quyền địa phương cần tập trung phát triển nguồn nhân lực trong dịch vụ du lịch, đảm bảo các vấn đề vệ sinh, an toàn an ninh trật tự tại địa phương, các điểm du lịch, hoàn thiện cơ sở hạ tầng và cơ sở vật chất kỹ thuật, chú trọng đến phát triển sản phẩm quà lưu niệm đặc trưng địa phương, nhất là ở các làng nghề, tăng cường quảng bá và xúc tiến, tăng cường tổ chức các sự kiện, lễ hội cũng như hoạt động dịch vụ giải trí về đêm để đáp ứng đa dạng nhu cầu du lịch của du khách. Một khi cải thiện các vấn đề trên thì sẽ góp phần nâng cao sự thu hút của Phú Quốc đối với du khách, đồng thời cũng góp phần nâng cao sự hài lòng và lòng trung thành của khách du lịch khi đến đây.

\section{TÀI LIẸU THAM KHẢO}

Benur, A. M., \& Bramwell, B. (2015). Tourism product development and product diversification in destinations. Tourism management, 50, 213-224.

Field, A. (2009). Discovering statistics using spss third edition. Sage Publications Ltd., London.

Formica, S. (2000). Destination attractiveness as a function of supply and demand interaction. Virginia Polytechnic Institute and State University.

Harris R., \& Howard J. (1996). Dictionary of travel, tourism and hospitality terms. Hospitality Press.

Hair, J. F., Tatham, R. L., Anderson, R. E., \& Black, W. (1998). Multivariate Data Analysis ( $\left.5^{\text {th }} \mathrm{Ed}\right)$. Prentice-Hall.

Hoàng Thị Kiều Oanh. (2019). Đánh giá tài nguyên du lịch và điều kiện sinh thái khi hậu phuc vu phát triển du lịch vùng Nam Bộ Việt Nam (Luận án Tiến sĩ). Học Viện Khoa học và Công nghệ.

Hoàng Trọng \& Chu Nguyễn Mộng Ngọc. (2008) . Phân tích dũ liệu với SPSS - Tập 2. Nhà xuất bản Hồng Đức.

Hu, W., \& Wall, G. (2005). Environmental management, environmental image and the competitive tourist attraction. Journal of Sustainable Tourism, 13(6), 617-635.

Hui, T. K. \& Wan, T. W. D. (2003). Singapore's image as a tourist destination. International Journal of Tourism Research, 5(4), 305-313.

Kozak, M., \& Rimmington, M. (1998). Benchmarking: Destination attractiveness and small hospitality business performance.
International Journal of Contemporary Hospitality Management, 10(5), 184-188.

Lew, A. A. (1987). A framework of tourist attraction research. Annals of Tourism research, 14(4), 553-575.

Lê Văn Huy \& Trương Trần Trâm Anh. (2012). Phưong pháp nghiên cứu trong kinh doanh. Nhà xuất bản Tài chính.

Nguyễn Anh Tuấn. (2010). Năng lực cạnh tranh điểm đến của du lịch Việt Nam (Luận án Tiến sĩ). Trường Đại học Kinh tế - Đại học Quốc gia Hà Nội.

Nguyễn Đình Thọ. (2011). Phuoong pháp nghiên cúu khoa hoc trong kinh doanh. Nhà xuất bản Lao động-Xã hội.

Ngwira, C., \& Kankhuni, Z. (2018). What attracts tourist to a destinations? Is it attractions?. African Journal of Hospitality, Tourism and Leisure, 7(1), 1-19.

Pandey, R. N., Chettri, P., Kunwar, R. R., \& Ghimire, G. (1995). Case study on the effects of tourism on culture and the environment - Nepal: Chitwan-Sauraha and Pokhara-Ghandruk. UNESCO Principal Regional Office for Asia and the Pacific.

Richards, G. (2002). Tourism attraction systems: Exploring cultural behavor. Annals of Tourisn Research, 29(4), 1048-1064.

Swarbrooke, J. (1999). The development and management of visitor attractions. ButterworthHeinemann.

Thanh Thanh. (2020). Án tương Phú Quốc. Truy cập từ: https://congthuong.vn/an-tuong-phu-quoc131724.html\#: :text=N\%C4\%83m\%202019\%2 C\%20Ph\%C3\%BA\%20Qu\%E1\%BB\%91c\%20 $\%$ C4\%91\%C3\%B3n,Anh\%2C\%20\%C3\%9Ac\% 2C\%20Th\%Е1\%BB\%A5y\%20\%C4\%90i\%E1\% $\mathrm{BB} \% 83 \mathrm{n}$.

Thủ tướng Chính phủ. (2020). Quyết định của Thủ tuoóng Chính phủ : Phê duyệt Chiến luợc phát triển du lịch Việt Nam đến năm 2030 (Số 147/QĐ-TTg). Hà Nội.

Trần Linh. (2018). Khách du lịch đến Kiên Giang năm 2017, kế hoạch năm 2018. Truy cập từ: https://sdl.kiengiang.gov.vn/trang/TinTuc/116/60 0/KHACH-DU-LICH-dEN-KIEN-GIANGNAM-2017--KE-HOACH-NAM-2018.html

Trương Trí Thông. (2019). Các nhân tố thu hút du khách đến du lịch biển đảo ở huyện Kiên Hải, tỉnh Kiên Giang. Tạp chi Khoa hoc Truờng Đại hoc Cần Tho, 55(4C), 113-122.

Vengesayi, S. (2003). A conceptual model of tourism destination competitiveness and attractiveness. Conference Proceedings. December, 1-3, 2003. Monash University, 637-645.

Zhou, L. (2005). Destination attributes that attract international tourists to cape town (Master Thesis). University of the Western Cape. 